\title{
EVALUATION OF PHARMACEUTICAL CARE SERVICES' QUALITY IN LATVIA: THE CASE STUDY OF “MENESS APTIEKA"
}

\author{
Evija LIEPA ${ }^{1}$, Joanna HERNIK ${ }^{2}$, \\ Gunta GRINBERGA-ZALITE ${ }^{3}$, Anete MATUTE ${ }^{4}$
}

\author{
${ }^{1}$ Dr.math, assistant professor, Latvian Business College, Riga, Latvia, \\ e-mail: eliepa2@gmail.com, phone: +37129557195 \\ ${ }^{2} \mathrm{PhD}$, professor, West Pomeranian University of Technologies, Szczecin, Poland, \\ e-mail: joanna.hernik@zut.edu.pl, phone: + 48601721506 \\ 3 Dr.oec, associate professor, Latvia University of Agriculture, Jelgava, Latvia, \\ e-mail: gunta.grinberga@llu.lv, phone: +371 29463545 \\ 4 Mg. pharm, pharmacist, JSC “Sentor Farm aptiekas", Jurmala, Latvia, \\ e-mail: anetematute@gmail.com, phone: + 37129722155
}

\begin{abstract}
The availability of quality pharmaceutical care services is an important precondition for the nation's welfare, therefore their quality maintenance and regular evaluation is one of the main challenges that pharmacies have to deal with. Based on the previous studies of theoretical fundamentals of service quality, the authors have set the research aim to apply SERVPERF and SERVQUAL methods of service quality evaluation for identifying the quality gaps in "Meness aptieka" pharmaceutical services. Retrospective evaluation of service quality can only partly show if quality is at sufficient or insufficient level, therefore authors recommend service providers to use a combined quality evaluation system which includes both identifying of customer expectations and their real experience, afterwards comparing those evaluations to detect gaps in real performance. The research results showed that the quality of the four surveyed "Meness aptieka" pharmacies' services in Jurmala is at high level and meets customer expectations. There were few minor quality gaps detected, among which most important was customers' dissatisfaction with new product promotions in pharmacies, which are perceived rather as aggressive sales than holistic care for customer's health.
\end{abstract}

Keywords: pharmaceutical care services, service quality, SERVPERF, SERVQUAL. JEL code: $L 15, L 84$

\section{Introduction}

The health of population is one of the most important prerequisites for public happiness and welfare. Nowadays, medicinal products are an indispensable and essential part of health care services in all cultures and societies. Available access to medicine is a crucial precondition for many disease prevention programmes and the treatment component of virtually all diseases. Equally important is the pharmacist who is specifically educated and trained health care professional, to whom the company has entrusted the distribution of medical products. In order to deal with 
health-related needs of the population, pharmacists are assuming increasing responsibility for the final outcome of medical treatment and are expected to improve their experience on regular basis to consult people not only about medical products, but also actively get involved in holistic health promotion, disease prevention and prevention-related services.

However, after visiting the website "sudzibas.lv" ("complaints website " that accumulates various negative comments, references about products and services in Latvia, and thus can be regarded as a "black list" indicating companies with negative reputation), the authors conclude that the population of Latvia quite often complains about the quality of pharmaceutical services in almost all pharmacy networks. Although it is impossible to fully trust those references, it still shows the most problematic areas with which the management of pharmacy networks has to deal with. Almost all complaints with a few exclusions have been addressed to unsatisfactory rendering of services, i.e. pharmacist's work (poor knowledge of languages, indifferent attitude, rudeness, insufficient competence, poor knowledge of active components in a product etc.). Since the market of pharmaceutical care services is mature and saturated in Latvia including both local and international capital intensive pharmacy chains, the management of pharmacies is highly interested in opportunities to timely identify the gaps in service provision. However, up to now pharmacies mainly have focused on retrospective evaluation of service quality, most often using a "secret customer" method. The authors of the article have aggregated scientific literature on service quality to search for new opportunities how to manage service quality more efficiently taking into consideration not only management's objectives, but also customers' expectations, which in authors' opinion is an important driving force of the development of contemporary and high quality services of pharmaceutical care.

The aim of the present research is, basing on the SERVPERF and SERVQUAL methods of service quality evaluation, to identify the quality gaps in "Meness aptieka" pharmaceutical services. The object of the research is service quality evaluation. The subject of the research is service quality evaluation in "Meness aptieka" pharmacies. The authors have formulated the hypothesis: quality disconfirmation models are easy to adapt and useful for constant monitoring and perfection of pharmaceutical services.

The tasks of the research were:

1. to describe alternative theoretical models for service quality evaluation; 
2. based on the theoretical fundamentals of service quality, to define the quality dimensions of pharmaceutical care service;

3. to perform empirical investigation of service quality disconfirmation model and identify the quality gaps of "Meness aptieka" pharmaceutical care services.

\section{Scientific methods}

In the research work, theory analysis was applied to aggregate the most important aspects of service quality evaluation. Analytical method was applied to investigate the dimensions of a pharmaceutical service product and perform gap analysis of its quality. Statistical method (SERVQUAL) was applied to aggregate "Meness aptieka" customers' service evaluations. Logical construction method was applied in the conclusion part to present the authors' conclusions about the results of the research.

\section{Research results}

The brand owner of pharmacy companies "Meness aptieka" and wholesaler "Recipe Plus" is JSC "Sentor Farm aptiekas" that is incorporated in a local holding company JSC "Repharm". JSC "Sentor Farm aptiekas" was founded in 2003. "Recipe Plus" medicine wholesaler was established in 1995. "Recipe Plus" company's share capital is 1643416 EUR, and it is the provider of medicine and medical products for 750 Latvian pharmacies and more than 100 medical facilities. "Sentor Farm" company's share capital is 199202 EUR. This pharmacy company incorporates more than 220 pharmacies and 12 subsidiary pharmacies in Riga and regions of Latvia, thus it can be regarded as the leading player of the industry (Meness aptieka, 2016).

A significant tool for enabling constant monitoring and perfection of provided services for all customer groups is company's quality assurance program. The headstone of "Meness aptieka" quality assurance is its internally organized "secret customer" visit that is regularly used in all pharmacies of "Meness aptieka" chain.

The study of the scientific literature on service management and marketing reveals the complicated nature of a service product. The basic attributes that make it different from a good are services' intangible character, inconsistent performance, the fact that services are more a chain of activities but not goods, the fact that services in most of cases are produced and consumed simultaneously and at last the fact that a service product value is created in the process of seller's and buyer's interaction (Solomon et.al., 2008; Palmer, 2015). Because of lack of hard measures, statistical quality control techniques are not always as successful in 
services as they are in manufacturing. Therefore, service quality measurement requires other tools specially designed to measure service product as a set of tangible and intangible benefits (Grönross, 2007).

Service quality researchers, represented by Zeithaml et.al., (1988), Cronin, Taylor (1992), Mc Alexander, Kaldenburg (1994), have aggregated all service product contents in so called five service quality dimensions: tangibles, reliability, responsiveness, assurance and empathy. Each of the dimensions includes 4-5 criteria; consequently a service product is composed of 22 criteria from five dimensions. The five quality dimensions of a service product are: (1) tangibles (material benefits); (2) assurance (competence of the staff, knowledge and professionalism) (3) reliability (ability of the staff to perform the promised service dependably and accurately); (4) responsiveness (promptness and helpfulness of the staff to render the service timely, efficiently); (5) empathy (staff's individualized attention, understanding of the customer's special requirements).

Given the complex nature of services quality, it is not surprising that there have been divergent views about the best way to conceptualize and measure it (Palmer, 2007). To practically evaluate service quality in a company, there are basically two different approaches: (1) performanceonly evaluation (hereinafter SERVPERF); (2) disconfirmation models (hereinafter SERVQUAL).

SERVPERF is a performance measurement tool, which is a survey, consisting of 22 questions about the performance of the five quality dimensions. Usually for the evaluation of a service quality a Likert scale from 1 (strongly agree) to 7 (strongly disagree) is used.

It is the simplest approach to measuring service quality which intends asking customers to rate the performance of a service. The approach, which is revealed in the formula below, developed by Cronin and Taylor in 1992 , illustrates the way how it is accomplished in practice.

$$
S Q_{i}=\sum_{j=1}^{k} P i j
$$

SQi - person's 'i' perceived service quality

$\mathrm{k}=$ service criteria/units

$\mathrm{P}=$ person's 'i' perception regarding the service criterion ' $\mathrm{j}$ ' performance.

Another approach is SERVQUAL. By this approach a service is deemed to be of high quality when customers' expectations are confirmed by subsequent service delivery. Because of the emphasis on differences between expectations and perceptions, this model is often referred to as 
disconfirmation model. The same survey questions as in SERVPERF are asked, only in this approach there are two survey parts: Part A expectations regarding a service product quality and Part B - real performance of a service product quality. Measures of service quality can be derived quite simply by subtracting expectation scores from perception scores (Palmer, 2007). This approach, which has been developed by Zeithaml, Berry and Parasuraman in 1988, is illustrated in the formula below.

$$
S Q_{i}=\sum_{j=1}^{k}\left(P_{i j}-E_{i j}\right)
$$

SQi - person's 'i' perceived service quality

$\mathrm{k}=$ service criteria/units

$\mathrm{P}=$ person's ' $\mathrm{i}$ ' perception regarding the service criterion ' $\mathrm{j}$ ' performance $E=$ person's 'i' expectations regarding ' $j$ ' criterion of service quality

Since "Meness aptieka" already uses a "secret customer" quality control method, authors' intention was to practically test the SERVQUAL methodology. According to SERVQUAL methodology, the authors elaborated and performed two surveys: the first one (A survey) was organized to find out general expectations of the population regarding pharmaceutical care services and the second one (B survey, which complies with SERVPERF survey) was used to evaluate real performance of service quality in five pharmacies of "Meness aptieka" chain that are located in Jurmala. Authors' intention was to find out if quality of five Jurmala pharmacies complies with average expectations that population generally have regarding pharmaceutical services in Latvia. " $A$ " part survey was organized as an online survey during January-March 2016 and in it 103 valid replies were received. Whereas "B part" survey was organized during January-March 2016 in five different concept (different locations, sizes, specializations, target markets, turnovers) pharmacies of Latvia resort city Jurmala, which hereinafter are called pharmacies $\mathrm{X}, \mathrm{Y}, \mathrm{Z}$, and $\mathrm{T}$, where authors personally interviewed incoming customers, thus obtaining 86 answers.

In order to perform quality evaluation in "Meness aptieka" chain, the authors have adapted survey questions (by changing their content and reducing their amount to nine questions) and titles of the five dimensions so that they more precisely fit to the specifics of the pharmaceutical service: (1) material benefits: questions 1-2 (pharmacy interior, decorations); (2) assurance: questions 3-4 (competence, product and price labels, placement, merchandizing); (3) innovations: question 5 
(introducing customers with new products); (4) reliability: questions 6-7 (ability to receive health control tests; pharmacist's appearance, language knowledge etc.); (5) empathy: questions 8-9 (willingness to help, personalised care, tolerance etc.).

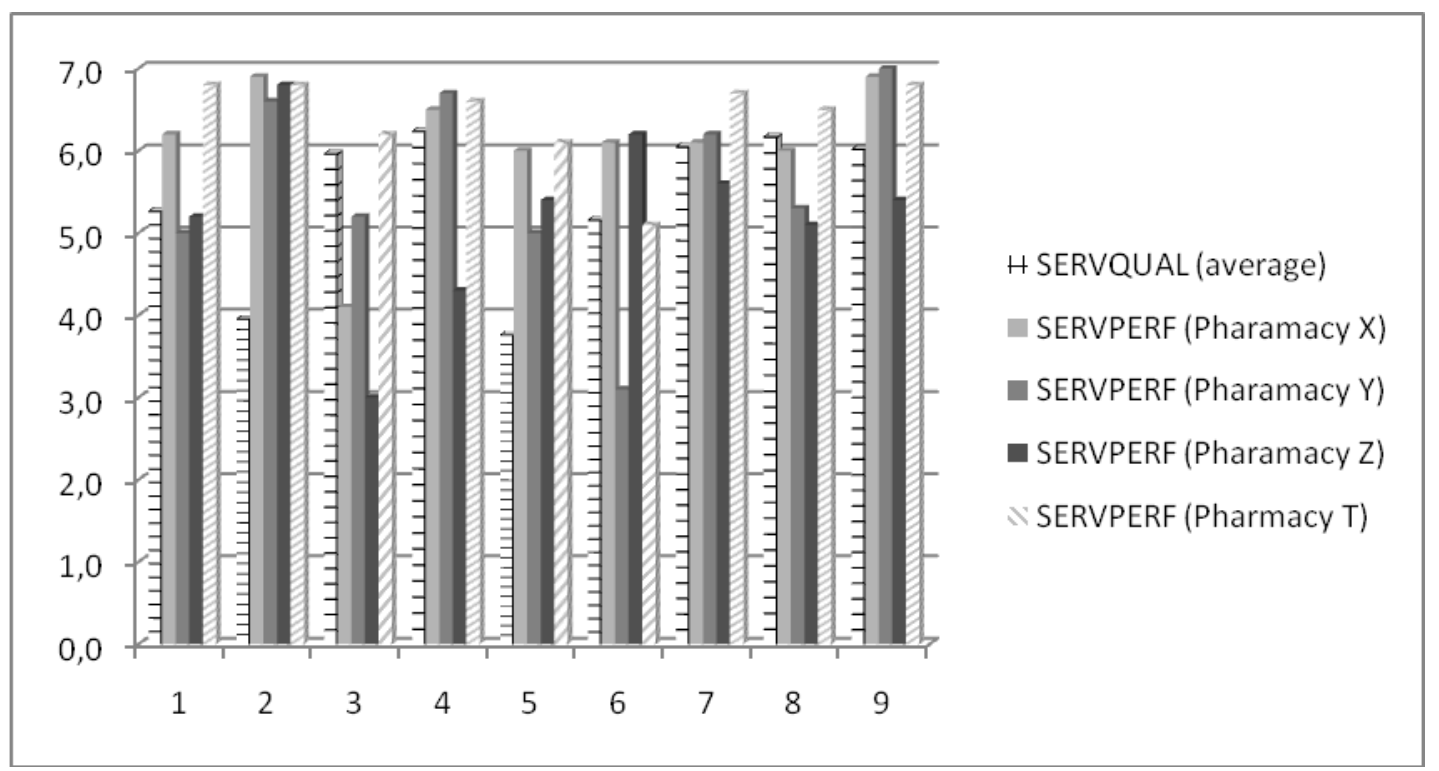

Figure 1. Comparison of SERVQUAL (expectations) and SERVPERF (real performance) survey results in "Meness aptieka" four pharmacies (Source: Matute, 2016)

Figure 1 reveals that both in pharmacy $\mathrm{X}$ and $\mathrm{T}$ interior and decorations (question 1) exceed customers' expectations, whereas in pharmacies $\mathrm{Y}$ and $\mathrm{Z}$ almost meet customer expectations, which in general means that in these pharmacies material dimension of the pharmaceutical services is optimal and complies well with customer needs. Question 2 was focused on finding out if customers appreciate the availability of customer rest area, and here customers' answers show that such area in fact is unimportant for them. Accordingly, in pharmacies could use this area for other better purposes. Regarding product placement and visibility of prices (question 3), only pharmacy T meets customer expectations. The rest of pharmacies due to different reasons have caused customer disappointment (insufficient space, dark, empty shelves etc.), however, it must be emphasized that this aspect in the overall pharmaceutical service is important to customers. Question 4 inspects if pharmacist is able to provide quality advice, explanation about pharmaceutical products. The results show that this aspect is important for customers. The research data show that all pharmacies (except pharmacy Z) have indicated very good performance of this criterion, which has to be evaluated positively. Respondents' answers on question 5 show that in all pharmacies customers are regularly informed about the new products, however 
customers do not highly appreciate availability of such information. The pharmacists involved in the research reported about many critical comments from customers who showed their dissatisfaction with wasting their personal time and unwillingness to listen to the new product advertising. Question 6 deals with assessing customers' experience with using health control services (e.g. blood pressure, weight control etc.). In this aspect, respondents' answers differ within the four pharmacies. In pharmacies $\mathrm{X}$ and $\mathrm{Z}$ customer expectations are exceeded, in pharmacy $\mathrm{T}$ they are not exceeded, but in pharmacy $Y$ they are not delivered. The explanation to pharmacy's Y low evaluations could be justified by the fact that this pharmacy is located inside the hospital, thus "Meness aptieka" does not provide these service leaving them in profession doctors' area of competence. Respondents' replies to question 7 give evidence that professional competence of pharmacists is high in all pharmacies, except pharmacy Z. This pharmacy could be characterized as the one with smaller turnover, lower income customers, less attractive location, which makes this pharmacy a less attractive workplace for young and perspective specialists and thus forces the management to employ here pharmacists with less motivation to work better. Question 8 was focused on finding out if pharmacists are interested to satisfy customers' needs, are kind, sympathetic to every customer. The replies show that unfortunately only pharmacy T can meet customers' expectations regarding this aspect. The authors suggest that in such a situation the management should try to find out what exactly are the reasons for this pharmacy's positive evaluations and possibly apply benchmarking to transfer to other pharmacies the methods, approaches and system that are used in pharmacy T. The respondents' answers on the question 9 indicate that all pharmacists (except those from pharmacy Z) provide extensive, topical and clear information about the products, and customers' expectations are even exceeded in this aspect, which gives evidence of professionalism and responsiveness of "Meness aptieka" pharmacists.

\section{Conclusions and suggestions}

The analysis of theory leads to the conclusion that service quality evaluation is more complicated than evaluation of goods quality because services are intangible and mostly are consumed and provided simultaneously. Important component of the service product is its implementer. The analysis of pharmaceutical services clearly show that the role of pharmacist is highly important in the overall performance of the pharmaceutical service, therefore extensive quality evaluations should be organized on regular basis. Retrospective evaluation of service quality ("secret customer" method) can only partly show if quality is at sufficient/ 
insufficient/ optimal level, therefore authors recommend service providers to use a combined quality evaluation system which includes both identifying of customer expectations and their real experience of using the service afterwards comparing those evaluations to detect gaps in real performance. Authors' research gave evidence that quality disconfirmations models are easy to apply and adopt for evaluation of pharmaceutical services. Moreover, such models ensure regular monitoring of service quality and ability to precisely detect the quality gaps in the overall service product.

In order to clearly identify the problem areas of the service, the authors recommend specifying various quality dimensions, e.g. material benefits, responsiveness of the staff etc., because often quality problems concentrate only in several particular areas that can be easily eliminated by the management.

In general, the quality of the four "Meness aptieka" pharmacies services in Jurmala city is at high level and meets customer expectations. The management of "Meness aptieka" has to re-engineer the present approach of innovative/new product promotion at pharmacies because customers do not appreciate or even find it obtrusive if pharmacists actively recommend new products, and thus new product promotions are more perceived as aggressive sales than holistic care for customers' health by offering them the latest and improved performance products.

\section{References}

1. CRONIN J. J., TAYLOR S. A. (1992). Measuring Service Quality: A Re-examination and Extension. Journal of Marketing, Vol.56, No.3, p. 55-68.

2. FARMĀCIJAS PORTALS ĀRSTIEM UN FARMACEITIEM. VISS PAR FARMĀCIJU. http://farmacija-mic.lv/meness-aptiekas-un-recipe-plus-turpmak-vadisdmitrijs-juskovecs/ [viewed online 20.04.2016]

3. GRÖNROOS C. (2007). Service Management and Marketing. Customer Management in Service Competition. Wiley; 3 edition, 2007, pp. 496.

4. LATVIJAS FARMACEITU BIEDRĪBA. www.farmaceitubiedriba.lv/lv/aktualitates [viewed online 20.04.16]

5. MCALEXANDER J. H., KALDENBURG D. O. (1994). Service quality measurement. Journal of Health Care Marketing, Vol.14, No.3, p. 34. McDonald M. (2004) Key Makreting Skills. 2nd edition. London: Peter Cheverton, p.198-222.

6. MENESS APTIEKA. ABOUT US. http://www.menessaptieka.lv/lv/aboutus/ [viewed online 21.04.16]

7. PALMER, A. (2014). Principles of Services Marketing. Berkshire, 2014, pp. 495.

8. SOLOMON M.R., MARSHALL G.W., STUART E.W. MARKETING. (2008). Real People, Real Choices. New Jersey, Pearson Prentice Hall, 2008, pp. 600.

9. ZEITHAML V., PARASURAMAN A., BERRY L. (1988). SERVQUAL: A Multiple-Item Scale for Measuring Customer Perceptions of Service Quality. Journal of Retailing, Spring, p.12-40. 


\title{
FARMACEITISKĀS APRŪPES PAKALPOJUMU KVALITĀTES NOVĒRTĒŠANA LATVIJĀ: „MĒNESS APTIEKA" SITUĀCIJAS ANALĪZE
}

\author{
Evija LIEPA ${ }^{1}$, Joanna HERNIK ${ }^{2}$, \\ Gunta GRĪNBERGA-ZĀLİTE ${ }^{3}$, Anete MATUTE ${ }^{4}$
}

\author{
${ }^{1}$ Dr.math, Latvijas Biznesa koledža, docente \\ $2 \mathrm{PhD}$, Rietumpomerānijas Tehnoloǵiju universitāte, profesore \\ 3 Dr.oec, Latvijas Lauksaimniecības universitāte, asociētā profesore \\ 4 Mg.pharm, AS „Sentor Farm aptiekas”, farmaceite
}

\section{Kopsavilkums}

Kvalitatīvu farmaceitiskās aprūpes pakalpojumu pieejamība ir būtisks priekšnosacījums jebkuras nācijas labklājībai, tāpēc aptieku sniegto pakalpojumu kvalitātes uzraudzības un kontroles aspektu loma aizvien pieaug. Latvijā veikto veselības nozares reformu un taupības pasākumu ietekmē farmaceitiskā aprūpe ir kḷuvusi par būtisku primārās veselības aprūpes sastāvdal̦u, tādēl šo pakalpojumu pieejamībai un kvalitātei tiek pievērsta aizvien lielāka uzmanība gan no nozares uzraugošo institūciju, gan sabiedrības puses, kas nosaka pētāmās tēmas aktualitāti. Balstoties uz iepriekš veikto pakalpojumu kvalitātes zinātniskās literatūras analīzi, autori uzstādījušu pētījuma mērksi izmantot SERVPERF un SERVQUAL metodes, lai noteiktu farmaceitiskās aprūpes pakalpojumu problemātiskās jomas "Mēness aptiekā", fokusējoties uz Jūrmalas teritorijā izvietotajām dažāda koncepta aptiekām. Tā kā pēc autoru domām retrospektīva pakalpojumu kvalitātes izvērtēšana spēj tikai daḷejji noteikt, vai kvalitāte ir atbilstošā vai neatbilstošā līmenī, tika izmantota kombinēta pakalpojumu kvalitātes novērtēšanas sistēma, kura paredz gan klientu gaidu noteikšanu, gan arī reālā izpildījuma novērtēšanu, noslēgumā salīdzinot abus šos rādītājus. Pētījuma rezultāti atklāja, ka četrās Jūrmalas aptiekās, kopumā n,emot, farmaceitiskās aprūpes pakalpojumi tiek sniegti augstā kvalitātes līmenī. Tomēr tika konstatētas arī atsevišksas pakalpojumu kvalitātes neatbilstības klientu gaidām, no kurām galvenā bija klientu neapmierinātība ar jauno produktu virzišanas pieejām aptiekās, kuras klienti uztver kā agresīvu tiešo pārdošanu, bet nevis holistiskas rūpes par klientu veselību. Konstatētās plaisas „Mēness aptieka” tīkla sniegto farmācijas pakalpojumu kvalitātē palīdz skaidrāk saskatīt prioritārās jomas, kas aptieku vadītājiem ir jāsakārto atbilstoši patērētāju gaidām.

Atslēgas vārdi: farmaceitiskās aprūpes pakalpojumi, pakalpojumu kvalitāte, SERVPERF, SERVQUAL. 